\title{
The founding narratives of the myth of economic development and the Brazilian neo-developmentalism
}

\author{
Rômulo Carvalho Cristaldo 12 \\ Juliana Rodrigues de Senna ${ }^{3}$ \\ Lara Sousa Matos ${ }^{2}$ \\ 1 Universidade Federal da Grande Dourados / Faculty of Administration, Accounting and Economics, Dourados / MS — Brazil \\ 2 Universidade Federal da Bahia / Postgraduate Program in Administration, Salvador / BA — Brazil \\ ${ }^{3}$ Vrije Universiteit, Amsterdam / The Netherlands
}

This article aims to interpret the most well-known theories of economic development based on the assumption that these theories are contemporary mythological tales and, consequently, the Brazilian 2000's neo-developmentalism agenda as an inexact unique blend of them all. The study uses Roland Barthes' semiotic interpretation on the social structure and roles of myths to argue that theories of development are rather a compound of ideologies than a scientific field of inquiry. In addition, the article draws a parallel between Joseph Campbell's hero's journey and the five widely known narratives of development: Protectionist, Keynesian, Institutional, Entrepreneurial and Neoclassical.

Keywords: economic development; capitalism; contemporary mythology; neo-developmentalism; economic science.

\section{As narrativas fundamentais do mito do desenvolvimento econômico e o neodesenvolvimentismo brasileiro}

O objetivo desse artigo é o de interpretar as mais conhecidas teorias do desenvolvimento econômico a partir da premissa de que se trata de narrativas míticas contemporâneas e, consequentemente, o neodesenvolvimentismo como uma mistura não necessariamente original dessas estórias. Faz-se uso da interpretação semiótica realizada por Roland Barthes acerca da estrutura e dos papéis sociais dos mitos para sugerir que as teorias do desenvolvimento funcionam muito mais como um arranjo ideológico do que como um campo científico. É também realizado um paralelo entre a noção de jornada do herói de Joseph Campbell e as cinco narrativas de desenvolvimento mais conhecidas: protecionista, keynesiana, institucionalista, empreendedorismo e neoclássica.

Palavras-chave: desenvolvimento econômico; capitalismo; mitologia contemporânea; neodesenvolvimentismo; ciência econômica.

\section{Las narrativas fundamentales del mito del desarrollo económico y el neo-desarrollismo brasileño}

El objectivo de este ensayo es interpretar las más conocidas teorías del desarrollo económico bajo la premisa de que son relatos míticos contemporáneos y, en consecuencia, el neo-desarrollismo brasileño solamente una mezcla no necesariamente creativa de estos cuentos. Se hace uso de la interpretación semiótica de Roland Barthes acerca de la estructura y las funciones sociales del mito para asegurar que las teorías del desarrollo funcionan mucho más como un sustrato ideológico que como un campo científico. Hace también un paralelo entre la noción de la viaje del héroe de Joseph Campbell y los cinco relatos típicos de desarrollo: proteccionista, keynesiano, institucionalista, emprendedor y neoclásico.

Palabras clave: desarrollo económico; capitalismo; mitologia contemporânea; neo-desarrollismo; ciencia económica. 


\section{INTRODUCTION}

Contemporary capitalism is led by schematic narratives of reality that, among their many roles, work to discipline choices, hopes, and behaviours of individuals, social groups and institutions. There are several examples, such as managerialism (Klikauer, 2015), the dichotomy between Islam and the West (Qureshi and Sells, 2003) and even the idea of representative democracy (Ayers and Saad-Filho, 2015). Our thesis is that the all-pervasive discourse of development is one of those tales. In particular, the idea of economic development appears to be full of assumptions, concepts, and conclusions inhabiting the grey area between scientific knowledge and fable. Development itself is often presented as the pot of gold at the end of the capitalist rainbow. Despite all its promises, however, development seems unachievable for most countries (Rivero, 2010).

As a result of the analysis performed here we found at least five major chronicles in three allegedly opposite political arenas competing to explain the processes of economic development and thus willing to influence decision makers. The first is the Neoliberal movement-bounded to the Neoclassical School of Economics-which claims that free market and freedom of choice can lead countries to a state of welfare equilibrium. Neoclassical economics has inspired other two narratives: the Entrepreneurial, that claims that technological innovations led by the entrepreneurial class is the real driving force of capitalist economies; and the Institutionalist, which maintains a growing interest on the role of institutions on inducing both economic and social change. On the other side of the political arena, we have two main schools: the Protectionist, whose narrative trusts that domestic capitalists and protected new industry structures—both supported by the National State-should lead an economy to heaven; and the Keynesian narrative which relies on macroeconomic planning to rule investment patterns and hence the growth of markets. Even if these five chronicles are believed to be on different sides politically, all of them assume a common cosmogonist (capitalist) interpretation of reality, trusting heroes, denouncing villains, and suggesting a moral conduct that, if closely followed, should take us to the paradise of development.

We followed the insights provided by the works of Furtado (1974), Rivero (2010), and Escobar (1995) to examine the founding premises of economic development as contemporary mythological narratives. The methodology used was a specialized literature review from an adapted discourse analysis, in which we read the development theories as if they were political speech, thus highlighting structural convergences and discrepancies. The main idea was to compare its key premises with the Joseph Campbell (2004) hero journey's categories. Following Roland Barthes (1972), we understand the myth as a semiotic structure which at the same time hides and displays-symbolically, but also as speech (understood here as a totality that involves what one says and how one acts) - social relations, agendas, and even entire worldviews. Our main hypothesis is that, apart from well-performed scientific argumentation-always relying on data, common sense and experience-development theories bear the responsibility of being one of the disciplinary structures of the capitalist society: a symbolic pattern of economic behaviour. To illustrate this discussion, we briefly analyse Brazilian neo-developmentalism, which has recently received copious attention for allegedly being responsible for keeping the Brazilian economy far from the hazards of the 2008's international crisis-until it didn't. The aggressive return of the 
neoliberal agenda under Temer's rule goes hand to hand with our argument: developmentalism is just another elaborated fantasy.

We pursued four specific objectives: first, we discussed the idea of myth as a semiotic structure ( $2^{\text {st }}$ section). Second, we analysed the shared background of development narratives, highlighting the common assumptions that comprise the cosmogonist framework from which their myths are drawn ( $3^{\text {nd }}$ section). Third, we interpreted major contemporary narratives of economic development as mythological storylines, pointing out their symbolic characteristics and structural convergences ( $4^{\text {rd }}$ section). Finally, we compared the theoretical background to the latest achievements of Brazilian neo-developmentalism ( $5^{\text {th }}$ section).

\section{THE MYTHOLOGICAL STRUCTURE}

The term 'myth', historically, has three meanings (Abbagnano, 2012). The first, from the classical period, stands that myths are mere verisimilar assumptions, inferior products of the intellect, aimed to explain different aspects of reality. Back then, myths were counterposed to 'truth', which was considered the real product of reason. The concept of myth as some kind of lower truth usually associates it to moral and/or religious discourse, as something that guides the relationship between men with himself, nature and God. Thus, the myth appears to be full of spiritual significance, especially because it functions as origin and reinforcement of certain beliefs. Following this first definition, a myth, in everyday language, can still be understood as something unattainable or something that opposes reason.

The second perspective, also according to Abbagnano, states that myths are forms of independent thought. They are not subject to rational reasoning, laying on a different level, endowed with the same status of scientific wisdom. Their truth, therefore, is not diminished or deformed, but authentic, although different, cloaked under a poetic form. It is in this context that the emotional foundation of the myth is recognized as distinguishing. It is not without reasonthat, within this context, Émile Durkheim stated that society, not nature, is the true model for the myth. According to this interpretation, the mythological speech, like most social projection, reflects, thereafter, the fundamental characteristics of social life (Durkheim, 1995).

The third interpretation yet following Abbagnano (2012) claims that the myth is a crucial element of every culture. The myth justifies its essential features reinforcing tradition, although it has only an indirect connection to historical facts. The anthropologist Claude Levi-Strauss, when analysing the structure of myths in ancient societies, noted that these social structures were not exactly historical narratives, but adjusted and improved representations of life events such as birth, death, struggle for survival, gender relationships, etc. (Levi-Strauss, 1970). For Levi-Strauss, myths can also express aspirations that can be triggered by real situations. It is this framework that interests us the most.

We can say, then, that myths can be understood as pseudo-historical tales and fabulous narratives. What is noteworthy in that third definition is that it emphasizes the social purposes of myths as human archetypes, which are rooted on socially shared concepts and projects, both derived from a collective symbolic repository. In accordance, Roland Barthes sustains that myths are discourses, a historically produced communication system that gives meaning and a social use to language. In other words, 
a myth is a semiotic system, which comprises '[...] the signifier, the signified and the sign, which is the associative total of the first two terms' (Barthes, 1972:111).

Barthes argues that the myth is a secondary semiological system because it is structured on a semiological chain that precedes it. According to Barthes, the sign (a fit between a signifier and its meaning) of the first semiological system is the signifier (e.g. first term) of the extended semiological system of the myth-therefore secondary. He then calls that signifier as language-object, for its use, through myths, to prepare its system of symbols. In other words, the myth itself appears as metalanguage, a second language which speaks through and about the first.

The myth as social process, hence, distorts the meaning of signs. It is defined by its intention, its concept, not by the literalness of its words, since they hide and/or miss the point. The myth, as 'speech stolen and restored' (Barthes, 1972:124), is never restored as stolen: it never comes back the same way, in the same scenery. It is precisely this gap, this furtive moment, that characterises the contravention of the mythical speech. Consequently, the myth neither reveals nor determines the concept: it naturalizes it, giving it the status of truth to be accepted without question. Its core lies in naturalizing history, in transmuting opinion into fact, especially if coated under an alleged scientificity.

The intentions behind the myth usually cannot remain hidden as it needs to be effective as disciplinary speech. A myth has to be perceived as evident and natural, as scientific law. Individuals tend to perceive myths as an inductive system, not as a semiological system of values. Where there is only a set of equivalences and/or coincidences people see perfect causal relations between variables. The myth is therefore usually read as a system of facts, as a true and unquestionable set of evidences.

Common sense understands myth as fiction, as something simply false or misleading. In contemporary society, however, at least one myth is not only real, but hyper-real: the myth of economic development (Baudrillard, 1991). Its ability to coordinate actions, to explain (while simplifying) mechanisms of social change, and to provide answers to unanswerable questions (e.g., about the existence of a human nature) reveals the augmented reality it convenes. As myths emerge from the concrete world, emphasizing while distorting, exposing while hiding, they bond with reality. Moreover, they lead people, social groups, companies and governments to act as if it they were true, to behave just as the mythological narrative demands, thus outshining reality itself.

The myth of economic development-with all of its compelling and competing narrativessimultaneously reveals and hides its deep sources grounded in the social division of labour and in those particular interests it represents and wishes to generalize. Although the modern myth of economic development offers several alternative narratives, it is built upon a set of normally unquestioned assumptions not necessarily dogmatic neither false, but hyperreal: it is a social construction elaborated as a symbolic structure that mimics the real world; it is a meta-narrative which lurks a tendentious interpretation of history and of the functioning of the economic system. Unlike what may thought Baudrillard (1991), we do not believe that this is just a matter of chance. The myth of economic development-its theories, premises, politics, think tanks, etc. - is part of a (not so much) hidden agenda of capitalism: it is bound not to develop countries but opportunities to valorise and accumulate capital. 


\section{SHARED ASSUMPTIONS OF THE MYTH OF DEVELOPMENT}

The idea of development is a product of the twentieth century. ${ }^{1}$ In fact, all the debate on how economic growth may lead nations to social progress appeared as fundamental to bureaucrats' discourses only after the Second World War. It was 1949 when Harry Truman, in his opening speech as US President, called for a collective effort from developed countries to assist the underdeveloped towards economic and social modernization. It was crucial to the core of capitalism, then, to commit with assisting the peripheral countries in order to maintain their loyalty. The mere existence of the USSR pointed out that the so called 'free world' should be at least as compelling to poor countries as communism. Some of these countries, during and after their decolonization process, required new status within the capitalist international system to remain under its rules. Political and economic self-determination were their agenda. The bipolar world that emerged in the second half of the twentieth century challenged the capitalist system to be better than socialism, both economically and politically (Escobar, 1995; Santos Filho, 2005).

Moreover, the ideology that sustained pre-War imperialism was outdated: the 'white man's burden' justifying the Western crusade to civilize through direct rule could no longer be effective, since nothing could be more barbaric than (white led) Nazism. The moral ground of pre-War imperialism was lost and so another myth was required to replace it. That is when the myth of economic development was established. Though it shares the same foundations of the 'civilizing' thesis, the myth of development is grounded on slightly different assumptions: from 'civilized' opposing 'barbaric' emerged 'developed' opposing 'underdeveloped' as valid criterion for international hierarchical classification (Escobar, 1995).

Following that narrative, differences among 'stages of development' were never credited to a rigid international division of labour. The myth of economic development sought to emphasize how underdevelopment would be caused strictly by internal conditions, especially by technical backwardness of production and by lack of capital. The myth influences not only the diagnosis but it also feeds the tale that it would be possible for all nations to achieve the standards of living and consumption of developed countries. The prescription goes at follows: it would suffice to follow the steps determined by those enlightened developed nations and so the path to wealth would be open (Escobar, 1995; Furtado, 1974).

Some basic assumptions of those development narratives already spell out their mythological trait: (1) the 'homo economicus' and its corollary rational behaviour as the standard agent; (2) social development as synonym of economic growth; and, (3) the possibility for all countries to simultaneously reproduce the standards of living of the rich-which means that the gap between developed and underdeveloped would diminish, as the latter would 'catch up' (Chang, 2002:38).These are the main assumptions that sustain the theoretical core of most development narratives, although each one of them has been contested at length by social sciences.

\footnotetext{
${ }^{1}$ Developing, then, replaces the narrative of civilizing barbaric nations, predominant during the Colonial Era. We do not wish to say that the idea of progressiveness did not exist, but to emphasize that the discourse of development becomes hegemonic just after the Second World War.
} 
The idea that human nature is driven by economic gain is entrenched in the foundations of the development reasoning. One of the first intellectuals to suggest that the human behaviour could be reduced to material self-interests and instrumental rationality was John S. Mill (Persky, 1995). Mill argued that human action derives from a rational calculus resulting from the tension between the dual possibility of pain and pleasure. Individuals would be guided by egoistic principles in order to maximize the utility of their choices-in other words, to reduce pain and increase pleasure. Despite being subject to severe criticism, that reasoning still provides the basis for most theories of economic choice, from neoclassical (Boettke, 1996) to Keynesian approaches (Coddington, 1974).

The principle of qualitative hedonism, which underlies the classical utilitarianism as well as the subsequent attempts to qualify 'pain' and 'pleasure', stumbles on its inability to precisely describe what maximization is. As Alain Caillé sugests, sometimes the subjective existence of individuals resists this materialistic reductionist explanation (Caillé, 2001). In addition, the notion of rationality is also quite weak. One part of the theory believes that is possible to parameterize preferences, falling into a tautology and/or totalizing a useless definition of will. When, however, they argue about bounded rationality, they still sustain that human action 'has to' be driven by reason (very scientific!), solely showing its limits concerning information processing (Caillé, 2001).

Another (failed) assumption of those theories is that from economic growth follow social and political development automatically. It is quite obvious for them that when an economy grows it demands progresses on Law, institutions, infrastructure, and politics. Furthermore, the alleged income distribution which would follow the economic growth would improve education standards, political participation, consumer behaviour, and social work differentiation. In other words, although most of the theorists distinguish between economic growth and development, they assume that the former unequivocally leads to the latter (Sunkel and Paz, 1976; Furtado, 1983). According to Theotônio dos Santos, still in the 1950s, the experience of some peripheral countries makes evident that it is possible for a country to increase its GDP without improving social and/ or political aspects (Santos, 2000). Growth per se has been proven not to be a sufficient condition to induce development.

The idea of development is also reinforced by the assumption that the standards of living of central countries can be widespread. This derives from a philosophy of history that presupposes the existence of a linear continuum of progress: advanced countries are so because they have followed certain steps towards civilization; one must only climb those same steps to get to the top of the ladder (nowadays a risible idea among serious researchers) (Escobar, 1995). The argument goes assuming that today's poor countries would be an example of how developed nations were in the past (they are not); their underdevelopment is just a stage to be overcome (it is not); and their future can be forecast as something resembling nowadays rich countries (they cannot) (Escobar, 1995; Santos, 2000; Santos Filho, 2005).

Celso Furtado (1974) claims that that kind of progress is not only impossible, but its underlying assumption also works as an instrument of control. First, natural resources reserves are finite and therefore unable to sustain the generalization of the standards of living of the central countries. Second, 
the presence of transnational corporations threatens developing countries autonomy by limiting their investment options and menacing their decision-making ability while being safety valves of saving for those companies homeland. Besides, the development strategies suggested by core countries are not able to ensure the progress of peripheral nations-on the contrary, they serve only to reassure income concentration for both local and foreign upper classes. According to Furtado (1974), the international aid for development, focusing on technological aid and foreign direct investment, has created a new dependency, especially in Latin America and Africa. ${ }^{2}$

Oswaldo Rivero, in turn, shows that after sixty years of theories of development, only four small countries reached ' $[. .$.$] a constant increase in the average rate of per capita revenue [...], in addition$ to technological modernization, a continuous process of income redistribution and a significant shift of population from poverty into the middle class' representing less than 3 percent of the nations of the world: 'two city-states, Singapore and Hong Kong (China), and two small countries, South Korea and Taiwan' (Rivero, 2010:2). The bulk of the remaining, according Rivero, are nowadays (some more, some less) 'quasi nations-states' where democracy it is just a shadow, self-determination is mostly a joke, economy is dependent and ruled by foreign corporations' agenda while its ruling classes are both inefficient and self-centred. A resounding failure. The economic theory of development, according to Rivero (2010), would serve only to mitigate the guilt of central countries while bringing false hope to the periphery (this hypothesis would still be kind, as it is not a matter of guilt, but of imperialism). Their economic policies, however, are still influenced by those mythological narratives, what we will now explore.

\section{FIVE TALES OF DEVELOPMENT}

It was the Economic Science-alleged source of wisdom, the oracle justifying every action of core capitalist politicians-that offered the narratives to beacon the notion of development. It would not matter whether the mainstream assumptions of most economic theoretical framework have been questioned by almost all other human sciences. Quoting James Carville: 'It's the economy, stupid!' (Kelly, 1992).

Keynesianism provided the first major tale of development. Competing directly with it was the neoliberal narrative, which put together the rational choice approach from Chicago (American liberalism) and the psychological liberalism (Austrian School), both inspired by the English neoclassicism of Marshal and the models of economic growth of Mead and Solow (Sunkel and Paz, 1976). Two derivations of the neoclassical theory emerged to provide other explanations for development. One, inspired by the work of Joseph Schumpeter, establishes that development derives

\footnotetext{
${ }^{2}$ Although Furtado classifies the well-known idea of development as a myth, he does not bother to address the notion of 'myth' itself in-depth. What is perceived through the analysis of his book-O mito do desenvolvimento economico (Furtado, 1974)-is that the word 'myth' is used there to refer to a deceptive even fallacious discourse. The same has to be said about the Owaldo's Rivero work-The myth of development (Rivero, 2010). We can say that both Furtado and Rivero brace 'myth' as a common sense synonym for 'false', thus missing the opportunity to deepen the understanding of the symbolic role of development narratives. Our view is that, though mythological, the development narratives herein analyzed play a concrete role on contemporary capitalist mode of production. That is the why we approach the idea of myth here from the Barthesian perspective discussed on section one (Barthes, 1972).
} 
from entrepreneurship and its innovation capacity. Another, whose main authors are Douglas North and Oliver Williamson, suggests that development depends on the existence of institutions to ensure the proper functioning of the market. A last approach relevant to this essay is the one inspired by Friedrich List (with large influence in Latin America), which emphasizes the importance of protecting infant industry to help countries in their development process.

Keynes' theory is as mechanic as any economic (mainstream) idea before him - and evenafter him, some say. ${ }^{3}$ His optimistic and in some way arrogant argumentation led him to draw up a defence of capitalism, believing the capacity of capital to promote welfare-his quest was only against laisser faire policies, claiming for a 'visible hand'. He therefore built a set of policies aiming to reform capitalism, saving it from itself through direct interventions of the State (Mészáros, 2005).

According to the Keynesian perspective, the major nemesis of the capitalist system is the economic cycle, a creature not entirely comprehended but widely known, which feeds from the capitalist tendency to create a savings glut (Keynes, 1936). The crisis of 1929 was not at all overcome when Keyne's General Theory...was published, nor was the corollary endemic unemployment, making it difficult for the recovering of rates of profit. In the 1930s, contrasting with the strengthening of socialist economies, the West was melting across the boarder (Douglas, 1986). A God had to be summoned to save the (free?) world. ${ }^{4}$

Keynesianism states that governments should take over the conducting of an economy during downward phases of the business cycle. When the (allegedly) automatic adjustment of the economy were to fail, the State should intervene to restore trust and expectations (faith?). Keynes does not say classic orthodoxy is entirely wrong-it is theoretically possible on the long-term. As Keynes himself liked to put it, however, on the long-term we will all be dead (Keynes, 1924). ${ }^{5}$

Keynes argues that a crisis does not result from an imbalance between supply and demand, but between supply and 'effective demand', stressing that it is the latter part of the equation that matters most. He argued that the effective demand depends on productive investments, which are lead by capitalist profit expectations towards the production process ex ante. In a context of crisis, such expectations would be low, limiting investment and decreasing job offers, feeding the downward of the business cycle. Governments should then intervene investing capital (Keynes, 1936). Keynes understood that capitalism would not heal itself through 'automatic' adjustments

\footnotetext{
${ }^{3}$ '[...] Keynes offers the most rigid and dogmatic separation of material/productive advancement [...]. He describes the process of productive reproduction from the mechanical "vulgar materialist" standpoint of what he himself calls "the economic machine", arguing with uninhibited optimism that science, technical efficiency and capital accumulation [...] are well on their way to solving, "gradually" of course, "humanity's economic problem" [...]. Unfortunately, though, a mere 42 years from the deadline set by Keynes himself for reaching our promised destination of "economic bliss", we are today much more distant from the mouth of the tunnel than 58 years ago, despite the tremendous advances in productivity accomplished in all these intervening decades.' (Mészáros, 2005:7-9).

${ }^{4}$ Osvaldo Sunkel and Pedro Paz argue that it is necessary to distinguish the thinking of Keynes from the theories inspired by him. According with them, the core target of Keynes' work was not development but a short-term government adjustment theory of economy. However, from the Keynesian thought emerged several economic growth models on long-term basis, as Domar's and Harold's (Sunkel and Paz, 1976).

5 'In the long run we are all dead. Economists set themselves too easy, too useless a task if in tempestuous seasons they can only tell us that when the storm is long past the ocean is flat again.' (Keynes, 1924:80).
} 
(e.g. waiting) if expectations were too low during a downward cycle. Governments should therefore speed the economic recovery by adjusting effective demand. A 'healthy' economy-one in which expectations are high-, however, need not such interventions, and so the 'hand' could go back to being 'invisible' (Keynes, 1936). ${ }^{6}$

From Keynes' ideas a whole branch of theories of development were brewed. Keynesian, postKeynesian, new-Keynesian and neo-Keynesian traditions (among other denominations and specific cults) argue for continuous state intervention in order to guarantee long-term development (Fazzari, 1989; Tymoigne and Lee, 2003). In simple terms, we can say that the guiding principle that binds such approaches together is the notion that it is necessary to socialize, through the State, the investment decisions of an economy. The once despised institution of the State overnight returned as a Phoenix from the ashes of the Old Continent. The faith was restored to conduce capitalism towards the promised land of development.

The Keynesian narrative puts the state bureaucracy as leading actor. Relying on its (alleged) aptitude on planning and programming an economy, whose interventions were believed to provide multiplier effects on private investment, State bureaucracy was the centre of the macroeconomic modelling. Keynesianism became a consensus and entered definitively the ivy league of economic thought during the post-War, crossing the bridge towards high politics. In a nutshell, with simple reasoning, arguing for constant state intervention to steer short and long-term investments (and, thus, economic growth), Keynesianism was a key advocate and believer of the tale of development (Singer, 1997). The supremacy of that narrative, however, would not last long. In the late 1970s, developed countries fell for another god. The revival of the liberal economic narrative founded the conservative inflection that we now call Neoliberalism (Harvey, 2005).

'Neoliberalism' and 'Neoclassical Economic Theory' are different but intertwined theoretical approaches - some may say 'social processes'. Neoliberalism is a well-known social, political, cultural and behavioural phenomenon, which emerged in the second half of the twentieth century as a massive class strategy. It began to be relevant in the 1960s, when conservative politicians, capitalists and representatives of the financial system took control over New York Unions. From the US it soon spread to the UK and then to other Western countries. The theoretical background of its economic agenda was (and still is) rooted on neoclassical economics, sharing with it a common fable about development (Harvey, 2005).

Although neoclassical economists constantly quote Adam Smith with reverence, most of his ideas remain largely unknown-if not refuted. In fact, there is just a fragile continuity between classical and neoclassical economic thought, except when it comes to a vague (but all-pervasive) idea of free market and, of course, when fiercely defending capitalism. Neoclassical economists believe that a country's economic system attain its best outcomes when there is no constrains to the economic decision-making. Although they validate this premise from theoretical models whose

\footnotetext{
${ }^{6}$ 'Again, if we have dealt otherwise with the problem of thrift, there is no objection to be raised against the modern classical theory as to the degree of consilience between private and public advantages in conditions of perfect and imperfect competitions respectively. Thus, apart from the necessity of central controls to bring about an adjustment between the propensity to consume and the inducement to invest, there is no more reason to socialise economic life than there was before.' (Keynes, 1936:202).
} 
detachment from reality borders the ridiculous, their ideas are the core of the economic science nowadays (Sunkel and Paz, 1976).

According to Sunkel and Paz, the neoclassical theory presents a static and mechanical system of the functioning of economies. To tell the truth, neoclassical economics does not have a development theory as we know it. In fact, they bring forward some economic growth models based on a simplistic interpretation of society. For them, economies are in constant and linear evolution lead by the increase of capital, which is explained by the industriousness of capitalists, by the constant technological innovations and/or by the existence of advanced institutions (Sunkel and Paz, 1976; Harvey, 2005). All this lively confirmed nowadays by economic modelling, econometrics and stochastic calculus.

The state (e.g. 'taxes') is the arch-enemy of the Neoliberal/Neoclassical narrative. According on their reasoning, the more you fund the state apparatus, the more you decrease market outcomes. Robert Solow, one of the most prominent neoclassics, concludes that in the long run economic growth converges to a static equilibrium, which leaves one and only one path for every country to achieve development, regardless of context determinants or political interventions. In addition, for Solow, all Sate interferences tend to raise inflation rates, as they put at risk the natural monetary equilibrium. State interference, therefore, hinders development by being innocuous, by reducing markets incomes and/or by triggering an inflationary process (Solow, 1956).

Markets are, then, the sole god of the Neoliberal/Neoclassical narrative. For them, decentralized decisions of (idealized) economic agents-fitted with rational expectations, able to dig and interpret countless information, armed with the price mechanism and seeking to maximize their satisfactionare naturally and automatically leading to development (Sunkel and Paz, 1976). Any form of control or intervention upon their holy actions might jeopardize progress (Solow, 1956). Capitalism and unbridled accumulation of wealth are as natural as breathing and eating: they are just human nature. Additionally, for them, economies have been evolving (or declining) based on those same principles since prehistory. Again, human nature. And the survival of the fittest.

The path towards development can thus be devised: free market must be guaranteed. At all costs. Better: cutting all costs. Not following that elementary condition leads surely to condemnation, to an economy of poverty and technological backwardness. The trick, according to Ha Joon-Chang, is that no developed nation ever developed through free market: on the contrary, protectionism is the ladder core capitalists used and now want to kick away (Chang, 2002). Regardless overwhelming historical evidence, the lesson stressed by Neoliberal/Neoclassical narratives is that economies are better off without interference. Markets can and should regulate themselves and sinners-poor countries only, as rich ones are still very much protectionists where it matters ${ }^{7}$ - that are still not entirely endorsing free market need to carry out basic reforms: deregulation and tax cuts (Williamson, 1990), especially for the super-rich. The paradise of development is just one more privatization away.

Rising from the neoclassical nest, but mostly influenced by the Austrian liberal economic thought, Joseph Alois Schumpeter devised an approach that sought to explain economic

\footnotetext{
${ }^{7}$ The Common Agricultural Policy of the European Union and US subsidies to agriculture being the most striking example.
} 
development through entrepreneurial appropriation of technical and technological innovationswhich we will here call the Entrepreneurial Narrative. Schumpeter's was predominantly trying to explain how technology could be linked to the ups and downs of capitalist economies, fluctuations which he tried to connect to what he called 'innovation cycles' (Schumpeter, 1997). The Austrian economist argued that the production process should have a central role, pointing out that its absorption of new technologies should not be considered an exogenous aspect of growth. On the contrary, he identified that most great economic advances could be identified as discontinuities lead by the diffusion of one or a pack of technological innovations and its influence on various business sectors.

According to Schumpeter, the changing of economies derives from some sort of new combination of power, raw materials and/or management practices, allowing a singular capitalist or organization to obtain competitive advantages. These advantages could grant them better prices, more reliable products and/or more efficiency, resulting in higher profits. Competition would then compel other capitalists to keep up with those innovations, either through imitation or through improvement, leading the whole economy to growth. When spread around, the competitive advantages cease to exist, bringing the economy back to a lower rate of growth until a new cycle of innovation begins (Schumpeter, 1997).

Schumpeter points out that there are three essential variables that, if put together, can start an innovation cycle: innovation itself, entrepreneurial action and credit availability. The central element of the innovation process is the entrepreneur, a social actor who is not necessarily a capitalist, nor an inventor or even a scientist, but someone skilled enough to combine capital and technology in order to create new profitable businesses. To succeed, however, it is necessary for the entrepreneur to find available financial resources from actors willing to take the risk of investing on an original project. These three variables-innovation, entrepreneurs and creditwould form the tripod which supports the capitalist economic growth. In its absence, according to Richard Nelson (2006), the state would have to intervene through the creation of a national innovation system.

Notwithstanding its apparent innovative approach, the entrepreneurial narrative is a sequel of the neoclassical myth of development. Instead of the impersonal market, the entrepreneur became the leading character. This epic hero, blessed with superior capacity to assemble capital and scientific breakthroughs to the building of competitive firms from the ground, stands out amongst mere mortals. According to Schumpeter, the capitalist economy as a whole-e.g, the world-is driven by the appropriation of innovations (Schumpeter, 1997). The nemesis here is the imperatives of the business cycle, or better, the decline of the technological patterns from the preceding cycle.

The work of Schumpeter inspired an evolutionary economic theory, only shifting the focus to the organic metaphor with the public administration as its heart (Nelson and Winter, 1982). Economic development should rise, here, from innovation policies linking companies, universities and research centres through State funding. The main idea is to curb the indelible inefficiency of the state through civil research and capitalist appropriation of technology. Undoubtedly, a path 
to development that reinforces the importance of innovations, but making a colloquy out of the entrepreneurial monologue.

As the Schumpeterian thought, the New Institutional Economics (NIE) shares many of the assumptions of the neoclassical narrative, claiming to be its evolution (Hodgson, 1998). ${ }^{8}$ This branch adds renewed importance to institutions, arguing that they are vital to maintain the regularity of economic agent's actions. The existence of (good) institutions should curtail market transaction costs endorsing its efficiency and eliminating its potential failures. To fulfil their purposes, these institutions should be able to ensure property rights and freedom, which, according to Douglass North (2003), are preconditions for economic growth.

In the words of North, institutions are social constraints to human action. They manifest as formal rules, informal norms and enforcement mechanisms (North, 2003). Economic growth should take place if these constraints are able to guide economic decisions increasing the efficiency of transactions. North (along with Williamson and others) argues that institutions are effective in boosting development only if they are capable of inducing private investment-therefore sharing the (neoclassical) idea that private actors' economic decisions are unequalled efficient. Any constraints to the actions of private companies and decision makers should be avoided-which they call 'liberties'. For them is also essential that the economic system reward properly (e.g. maximize the profits of) private investments-which they call 'property rights' (North, 2003). ${ }^{9}$

At first, it seems that institutions are the shining knights of development for the Institutional Narrative, but their conclusions are less clear-cut, as institutions can either assist or hinder economic development. Looking closely, their heroes are two: fitting property rights and liberties. Building good institutions is, surely, the path to economic development but, as Oliver Williamson states, decision makers are capable of changing only the bottom level of social institutions (formal rules, laws and Government public policies) (Williamson, 1991), as informal norms and enforcement mechanisms are determined by the historical legacy of a society. In other words, although there are possibilities for change, that tends to be limited by past choices of a society, a process of 'path dependence' (North, 2003).

One feature these three last narratives share is the fact that they tends to ignore the different stages and context of development amongst nations. They present themselves as theories that seek to explain the dynamics of capitalism disregarding place, time and history. Some political economists, however, have for long been concerned with the specificities of underdeveloped countries when facing influence and competition under capitalism. The first favourite case of interest for those thinkers was the Prussian Imperium, when on its path to becoming the fully industrialized late $19^{\text {th }}$ century Germany.

Friedrich List was one of the first economists to suggest that development could be achieved by protecting infant industry (List, 1983). According to List, the state should be responsible for the

\footnotetext{
${ }^{8}$ In fact, institutional approach on economics embraces much more than NIE. We choose to emphasize here the neoclassical side because they have inspired much of the contemporary discussion regarding economic development (Hodgson, 1998).

${ }^{9}$ Categories such as 'liberty' and 'property rights' are used by NEI theorists as synonyms for 'freedom' and 'property' without clear definition, as if they were necessarily equivalent. Williamson at one point assessed this critique, but without a compelling solution. See Williamson (1979).
} 
welfare of its people. Having testified the English industrial revolution, List realized that it would be through the development of industries that humanity would reach its material aspirations. Economic growth, therefore, was a precondition. Accordingly, however, a domestic industry could not develop properly if it finds itself exposed to the competition of advanced and wealthier foreign companies. Nations, therefore, should protect their domestic infant industry through the action of the State.

From then until now, the infant industry argument-hereinafter Protectionist Narrative-has been refined and expanded, even rounding up some empirical examples of success to show off: Germany, Korea and Japan are noteworthy (Chang, 2002). Some researchers within this narrative suggest the maintenance of protectionist policies until the domestic industry attains an international level of competitiveness (Melitz, 2005).Others claim that infant-industry should be protected until able to cope with the state of art of industrial dynamics and its technology (Ederington and McCalman, 2011). Ha-Joon Chang, a major reverend of the contemporary protectionists, suggests that free market is a setback for the underdeveloped: when the core of capitalism prescribes it, they are only aiming at the maintenance of the status quo (Chang, 2002). The argument here is that the thought of Friedrich List survives.

The hero of the Protectionist narrative is, of course, the infant industry. As with every infant, they should be protected until they find themselves prepared to face the perils of foreign industry competition. The infant industry must, then, rely under the tutelage of state. Types, categories and focuses of protection vary with the theoretical interpretation chosen or with internal characteristics of the nation at issue. Thereby, the path to development appears clearly devised: starting by the forging of a domestic industry, a national state should then strengthen it and make it competitive enough for both domestic and foreign markets (Bresser-Pereira, 2009).

As we can see, the state here must not only act through countercyclical policies, as Keynes suggested, but also through fostering internal industry competitiveness. That means raising fiscal and cambial fences to keep away foreign wolves, developing human resources, devising an educational system capable of improving technological standards, carefully choosing what industries to be most assisted and, often, acting as a strategic facilitator among countless interests and goals of also countless capitalists.

When put in perspective, it seems to be that all of those narratives similarly resemble the structure of Joseph Campell's hero's quest, the monomyth. Mythological fables regarding singular heroes, says Campbell, from ancient Asia, Europe and America, share the same plot. Having the same structure, they go as following: a call for adventure leads to finding a mentor, which leads to facing an enemy only to culminate with the rebirth of a transformed better hero, a hero that walked the valley of shadows following a path of wisdom (Campbell, 2004). Our heroes' economic journeys are no less fantastic. First, we are presented with a quest (economic development), which leads to a mentor (Smith, Keynes, etc.), which leads to facing an enemy (the government, business cycles, etc.). The theories appear as the journey itself, conforming to a set of standard steps that must be followed to the letter, despite distinct historical paths, political structures, cultural features and/or natural resources among countries. Our heroes (state, entrepreneurs, market, etc.) shall not rest. 
In our opinion, the myth of development has crucial purposes in the occidental late capitalist culture, both social and material, including the processes of accumulation and reproduction of capital. Regarding the last, we can say that given the structural contradictions of the capitalist mode of production, as well explained by David Harvey (2014), it has a tendency of constantly growing and expanding. This is because these contradictions lead the capitalism to cyclical discontinuities, which take the form of economic crises-monetary constraints, overproduction, unemployment, declining profitability, and so on-, whose final settling is irreconcilable.

However, the dynamic of capital acts as a mitigating factor for those crises, insofar as it constantly opens new fronts of money inversions, surplus-value formation and capital accumulation. These new fronts are both opening new markets (regional, foreign, overseas, etc.), and reorganizing more and more social process in a capitalist way (turning everything into commodities and every profession in wage-earning labour for surplus-value formation). This continued expansion must be justified both politically and theoretically. As Arturo Escobar (1995) says, in the nineteenth century, when capitalist expansion materialized through the process of imperialism, this double justification appeared as the notion of progress, or the 'white man's burden' in order to civilize the barbaric world immersed in the darkness of irrationality. Nowadays, in goes under the ideas of 'modernization', 'globalization', and, from our perspective, 'development'. Nevertheless, all of it actually is, in fact, consequences of the movement of the capital (or rather, its endless escape thriller from the final crisis).

Besides, the general idea of development, alongside its journey narratives, has also a symbolic role in the contemporary capitalism. We think that is not just serving as a conscience relief to the rich countries, as Oswaldo Rivero (2010) states, but it goes deeper under the very faith in capitalism itself. One of the most important consequences of Marx's critics on the political economy in his wide known work-The capital-is the comprehension that the capitalist mode of production faces not one, but several struggles embedded in its structural contradictions. As Marx (1982) says in book one of The capital, if lead by widespread and uncontrolled liberalism-coeteris paribus-, capitalism may brawls with an increasing income inequality. ${ }^{10}$

Furthermore, if the State's Governments manages to induce effective demand in order to prevent cyclical downturns, unemployment and poverty-book two of The capital_, capitalism could run into liquidity and profitability crises. ${ }^{11}$ Still, if capitalism succeeds to shape a credit system to balance for the different circulation temporalities of the various types of capital and equalize the different profit rates-book three of The capital—, that may come with every sort of speculative bubbles, fictitious

\footnotetext{
${ }^{10}$ Regarding to that, We think it is quite interesting reading Thomas Piketty's bestseller, Le capital au XXIe Siècle, which shows how the capitalism in the past fortieth years, the eon of the neoliberal turn, produced a historically unprecedented amount of richness-largely fictitious, according to Chesnais (1996) - in the hands of so few. He may not works from the Marxian outlook, but his findings are particularly significant from this perspective. See: Piketty (2014).

${ }^{11}$ The North American economist James O'Connor made an excellent analysis on the problem of the Welfare State fiscal crisis, showing mostly that one of its critical triggers was problems in both liquidity and profitability in the core capitalist countries. In other words, keeping high effective demand rates became too costly to the capital there. See: O'Connor (2001). And see also: O’Connor (1984).
} 
capital detachment, and uncertainties in the processes of production and realization of surplus value. ${ }^{12}$ In other words, it seems that the general functioning way of capitalism is to jump from one crisis to another until the end of times, which is not cheerful at all.

Considering that the capitalist mode of production largely functions on the basis of expectations and confidence, it needs equally large amount of reassurance. We think that the idea of development-the main belief that capitalism can grow indefinitely and, at least in the end, be socially and economically fair-works as a counterweight to the overwhelming reality of the permanent crisis that it engenders (which is usually characterized as an out of the ordinary situation). In this sense, the development myth and its narratives give a symbolic meaning to the typical capitalist way of thinking and acting, which takes the appearance of genuine hope. In the same way, it helps to establish what behaviours both individuals and organizations should accomplish, and what behaviours they should avoid.

For instance, the Neoclassical-Institutionalist narrative suggests the prominence of property rights and liberties to catch $u p$; although the base form of primitive capital accumulation is, as David Harvey (2014) shows, an accumulation by dispossession (privatization of collective property); and, as Slavoj Zizek (2003) states, the true freedom of the capitalist world it is a choice between engage on the capital's circuit of reproduction or die. Indeed, the myth of development both justify actions and provide excuses, whereas contributes to the behavioural programming of economic actors. In addition, as there is not only one capitalism, but also many, alongside many forms of capitalist integration, we have several development narratives (see box 1).

BOX 1 THE FOUNDING NARRATIVES OF THE MYTH OF ECONOMIC DEVELOPMENT

\begin{tabular}{|c|c|c|c|c|}
\hline Narratives & Nemesis & Heros & Paths of Wisdom & Lessons \\
\hline Keynesianism & $\begin{array}{l}\text { Economic Cycle / } \\
\text { Lack of Effective } \\
\text { Demand }\end{array}$ & $\begin{array}{l}\text { State and its } \\
\text { Bureaucracy }\end{array}$ & $\begin{array}{l}\text { Socialization of } \\
\text { investments decision }\end{array}$ & $\begin{array}{l}\text { The role of the state on } \\
\text { performing countercyclical } \\
\text { polices }\end{array}$ \\
\hline Neoliberal / Neoclassical & State and Taxes & Free Market & $\begin{array}{l}\text { Liberalization and } \\
\text { Deregulamentation }\end{array}$ & $\begin{array}{l}\text { Economies are better off } \\
\text { without any interference }\end{array}$ \\
\hline $\begin{array}{l}\text { Neoclassical / } \\
\text { Entrepreneurial }\end{array}$ & $\begin{array}{l}\text { Decline of } \\
\text { Technological } \\
\text { Patterns }\end{array}$ & Entrepreneurs & $\begin{array}{l}\text { National Innovation } \\
\text { System }\end{array}$ & $\begin{array}{l}\text { The importance of } \\
\text { technological innovations }\end{array}$ \\
\hline
\end{tabular}

\footnotetext{
12 There are several works that helps us to understand the capitalist financial crises from a critical perspective, as, for example, Chesnais (1996), Harvey (2014), Mézáros (2009) Zizek (2011), among others. However, it is interesting how a declared truly believer such as Charles Kindleberger shows how financial markets are at most of the time subdued to irrational and openly irresponsible behaviours, actually in terms that even Karl Marx could generally may agree. See: Kindleberger (2000).
} 


\begin{tabular}{|c|c|c|c|c|}
\hline Narratives & Nemesis & Heros & Paths of Wisdom & Lessons \\
\hline $\begin{array}{l}\text { Neoclassical / } \\
\text { Institutionalist }\end{array}$ & Bad Institutions & $\begin{array}{l}\text { Property Rights and } \\
\text { Liberties }\end{array}$ & $\begin{array}{l}\text { Induce the emerging } \\
\text { of good institutions }\end{array}$ & $\begin{array}{l}\text { Path dependence may limit } \\
\text { growh possibilities }\end{array}$ \\
\hline Protectionist & Foreign Industry & $\begin{array}{l}\text { Infant industry / } \\
\text { state's government }\end{array}$ & $\begin{array}{l}\text { Protect infant } \\
\text { industry }\end{array}$ & $\begin{array}{l}\text { State's government should } \\
\text { intervene increasing } \\
\text { competitiveness }\end{array}$ \\
\hline $\begin{array}{l}\text { Fonts: Elaborated by } \\
\text { the authors, from the } \\
\text { references herein } \\
\text { analyzed. }\end{array}$ & & & & \\
\hline
\end{tabular}

As we can see on Box 1 above, most economic development narratives chose one and just one aspect of reality to consider as the main problem, their Nemesis. The lack of effective demand in an economic cycle for Keynesians, the State and its taxes to Neoclassicals, the decline of the technological patterns to Schumpeterians, bad institutions to those who follow Douglass North and Oliver Williamson, or the malevolent foreign industry competition to Protectionists, have the role of acting as a challenge to be faced. Pointing out to one singular problem simplifies reality, allowing the development narrative to prescribe just a few simple steps based upon a few direct causalities between variables that, if observed closely, are much more complex.

If we believe, for example, that the lack of effective demand causes the downturn of an economic cycle, we reasonably can rely on State to induce consume and inversions in order to revert it. However, by doing that, we just set aside the social processes which led the economy to a situation of hyperproduction, the problems of a large Bureaucracy, the environmental effects of exponential growth, etc. Not only each recipe for success takes only one or just a few variables to prescribe unchangeable steps to be followed, they also frequently develop an aversion, a true antagonism, towards (not always) competing alternative discourses.

Moreover, if we have villains, there has to be heroes. Those social processes, which are pointed out as key to solve all development problems, are usually offered as true champions. The way that Schumpeter describes the entrepreneur, for instance, both in the book of 1911 (Schumpeter, 1997) and in the book of 1942 (Schumpeter, 1961), has a mix of dazzle and wonder. The entrepreneur is characterized as courageous, intuitive, proactive, willing to take risks and resilient: a truly superior human being. In fact, Schumpeter goes as far as to suggest that entrepreneurs should be the legitimate rulers of our capitalist societies given their superiority. Again, relying just on one aspect grossly simplifies reality. Of course, all narratives have arguments to justify their choices for heroes: the market must be reinforced by prices mechanism, concurrency, and property rights, according to Neoclassical thinking; to Keynesians, the State needs a well-prepared Bureaucracy, alongside good statistical methods and reliable macroeconomic policies, everything to boost the capitalist animal instincts; the same can be said about the infant industry of the Protectionists, which relies mostly on State protection; good institutions need the rule of the law, which means that a State Bureaucracy 
should support it. As for the Schumpeterian school, the entrepreneur himself needs technological innovations, which allows him to obtain competitive advantages in order to face the established economic powers. Those justifications, however, do not make up for the disproportionate belief devoted to a single aspect of reality.

Each narrative is built in the form of a journey. The narratives here discussed follow only three of Campbell's 17-step structure: i, the call of adventure, or the problem of development; ii, the mentor, in our case, the scholars who devise economic development theories; iii, the road of trials, with its apparently easy beginning, or those initial years of development in which everything seems to go right). Although, we think they have their own specific structure for their hero's journeys.

Beyond the three mentioned phases directly related to Campbell's structure, each economic development narrative has: iv, a stage of compliance, where not the hero, but the society must accept the enlightenment of the theory as the only truth; $v$, the new order, in which the hero must be raised to the position of unquestionable government upon the collectivity; vi the excuses, when everything goes wrong and the new rulers are questioned about the reasons why they could not accomplish the development objectives (in every tale, the problem is always that the steps were not correctly followed). The solution presented, therefore, is to vii. deepen the reforms, where society has to make "sacrifices" in the name of a greater good. These two last steps, six and seven, are not part of any economic development narratives' cannon-but we can say that those are indeed the outcomes of the application of each of them (Ibarra, 2011; Moreno-Brid and Bosch, 2010; Souza, 2005).

Regardless of all of their unrealistic premises, the structural convergence of theses fables tells us much more about the capitalist way of thinking than about the causes (and limits) of development. These narratives are built as a recipe, whose differences are merely a result of some ingredients exchange to meet the tastes and interests of the cook. In our opinion, it does not matter if this nemesis/hero/ path/lessons structure are actually deliberate neither accidental. For instance, the possibility that we may reduce the most known theory of economic development to such mechanical patterns is symptomatic of its actual role in contemporary capitalism.

First, development narratives can be found in the basis of authority rhetoric, which are employed to justify all kind of unpopular and even hazardous Government measures, in times of war, crisis, but also peace and prosperity (Riaz et al., 2016). Second, we can say that the economic development tales works as ways to reinforce political agenda of classes and its fractions in their struggle on hegemony, as some kind of governance premises of action (Cristaldo, 2014; Santos and Gomes, 2014). In addition, the development idea replaces $19^{\text {th }}$ century utopias on the capitalist contemporary mind-set providing both (false) hope to the poor and peripheral, and liability relief for the rich and empowered (Lempert, 2014; Rivero, 2010). Most important of all, the development theory tries to sell measures to improve capital valorisation and accumulation claiming that at same time it would provide collective gains and social prosperity, which are not its real intent, on the contrary (Saull, 2015; Riley, 2015). Indeed, the theory of economic development works as a symbolic structuring of reality in the capitalist world system, simplifying it to provide a rational course of action, but also to secure particular standards. 


\section{ONCE UPON A TIME IN BRAZIL, THE NEO-DEVELOPMENTALISM...}

In the first decade of the $21^{\text {st }}$ century, a self-proclaimed new creed of redemption rose in Brazil. Neodevelopmentalism was born already bearing a consensus, echoing the cries of one pillaged Latin America against the neoliberal experience of the 1990s (Boyer, 2009). A full set of conventions and policies were devised to provide a theory allegedly able to lead those countries into the Olympus of the development. We can say that there were at least two kinds of neo-developmentalisms in Brazil. The first is largely theoretical and takes the appearance of political speech, taking the form of a mythic narrative just as the other tales alluded herein. Economist and former finance minister Luiz Carlos Bresser-Pereira, one of its first proponents and staunchest supporter, best represents this perspective (Bresser-Pereira, 2009). The second, mostly practical, derives from the reasoning of public policies carried out by Presidents Lula da Silva and Dilma Roussef (Boito Jr. and Berringer, 2013). The first is the narrative itself; the second, a simulacrum of its wishful thinking when taken the form of state policies.

According to Morais and Saad-Filho (2011), the expression in Portuguese novo-desenvolvimentismo was at first forged by that same Bresser-Pereira in 2003.13 Theoretically, the neo-developmentalism claims to be a third way, arguing that it opposes and incorporates both the Neoliberal/Neoclassical narrative-which Bresser-Pereira calls 'conventional orthodoxy' (2009:75) - and the old developmentalism, which refers to the strategies of development Latin American followed not so long ago. Bresser-Pereira argues that the neo-developmentalism is not a theory of economic development: he refers to it as a national development strategy. ${ }^{14}$

The theoretical framework of the neo-developmentalism was inspired by (very) different intellectual sources. From the classical political economy, it allegedly fuses Adam Smith with Karl Marx. Keynes comes through his followers: the neo-Keynesians Davidson and Stiglitz. Last but not least, Latin American (neo) structuralism is also enrolled as part of the set of references (Morais and Saad-Filho, 2011). It is as if Snow White were to help Adam and Eve to clean the Augean stables-an economically schizophrenic chimera.

By reviewing some of the latest works of Bresser-Pereira (2003, 2007, 2008, 2009, 2010, 2011 , 2012a, 2012b, 2013) and of his associates (Bresser-Pereira and Gala, 2007; Bresser-Pereira and Gala, 2010; Bresser-Pereira and Theuer, 2012) we can find the most interesting particularities of neo-developmentalism theoretical approach. Although it apparently has a sundry list of references, three general aspects prevail: part of the diagnosis deriving from Fajnzylber's work concerning

\footnotetext{
${ }^{13}$ Although the researchers involved in the neo-developmentalism currently claim that Bresser-Pereira is the author of this terminology, the word neo-desenvolvimentismo (in Portuguese) was already used by Ruy Mauro Marini (1992:91) in early 1990s. However, Marini employed the term to describe the development efforts orchestrated by the military putschist governments in Latin America in the 1970s, which Bresser-Pereira and his followers also treat simplistically as developmentalism alongside the typical ideas of the 1950s and 1960s.

${ }^{14}$ According to Filgueiras (2012), the word neodesenvolvimentismo (neo-developmentalism) would be the theoretical background we discuss here, whereas novodesenvolvimentismo (something like new-developmentalism) would stand for the policies actually conducted by the Brazilian government during PT's terms. Our interpretation, converging with Filgueiras, is that this differentiation is used to absolve neo-developmentalism inefficiency when put into practice by the government.
} 
the problems of the industrialization of 1980s Latin America; ${ }^{15}$ the emphasis on the failure of the neoliberal policies of the 1990s; and some sort of neo-Schumpeterian solution for those problems. According Bresser-Pereira, the import substitution industrialization, the hallmark of the old developmentalism put forth during the 1980s in Latin America, exhausted itself in a fiscal crisis. A convergence of factors then took place, especially the political pressure of foreign creditors under the blessing of the Consensus of Washington, pushing the region towards neoliberalism. Also according to Bresser-Pereira, however, neoliberalism was not only unable to boost development but it was also ineffective to promote the macroeconomic stability required to encourage private investments. As a matter of fact, the appreciation of the currency caused by the prescribed antiinflationary policies stifled the competitiveness of national industries, causing deindustrialization in some cases-what the author calls 'Dutch disease' -, while triggering or worsening the excessive indebtedness of Latin American countries (Bresser-Pereira, 2008).

One of the major critiques Bresser-Pereira addresses against the policies of conventional orthodoxy refers to what he calls their 'market fundamentalism. However, he suggests himself, several times, that markets are indeed the best way to organize economies, provided that they are controlled by institutions. He is not a neo-institutionalist, though: he rejects the conclusion of the NIE, arguing that a national development strategy led by the government is the key to development-instead of property rights and liberties. The strategy, therefore, should seek macroeconomic stability, the creating or maintaining of institutions to promote technological innovation and industrial competitiveness in foreign markets, and a timid expansion of the aggregate demand. In other words, the author claims that it is necessary a strong state to strengthen the markets (Bresser-Pereira, 2009).

Regarding macroeconomic management, Brazilian neo-developmentalism theorists suggests a pack of measures that should control and reduce uncertainties of the economic system. These procedures aim to provide a steady background that should foster private investment. To do so, the central bank-or the corresponding monetary authority-must seek to control inflationary pressures. Furthermore, the government ought to keep a balanced budget, either by emulating principles of the private sector to control current spending (Sicsú, Paula, and Michel, 2007) or by reducing the debt through stimulating domestic savings while keeping moderated interest rates (Bresser-Pereira, 2009). According to Bresser-Pereira, in order to keep macroeconomic stability it is strongly advised that the national state maintain its decision-making autonomy. Governments with difficulties rolling debt and hinges on short-term loans find themselves in a situation of dependency, which leads to an inefficacy of its economic policies, what undermines market itself.

Nevertheless, macroeconomic stability it is not enough to promote development. It has to be considered that underdeveloped countries coexist (and compete with) developed nations within a

\footnotetext{
${ }^{15}$ Fernando Fajnzylber (1983) in the early 1980s performed an analysis of the industrialization process of Latin América and found out that it has happened someway broken. If the countries of the region achieved some sort of increasing on its industrial park, that process lacked a capital goods segment. Indeed, although the strategies of import substitutions were actually successful, it resulted in technological dependency with the north, that the author called industrialización trunca.
} 
historical framework of (economic, political and sociological) dependency. Bresser-Pereira argues that the State must shape institutions to reverse the structural constraints that contribute to the maintenance of underdevelopment (Bresser-Pereira, 2010). The national development strategy should then include: i. Reforms to strengthen the state and the market; ii. Some sort of industrial policy to induce private investment and technological innovation; iii. Promotion of high valueadded exports; iv. Investments funded by domestic savings and; v. Foreign capital controls. ${ }^{16}$ All these steps (or institutions, as the author prefers) should increase competitiveness of domestic industry in international markets.

The proponents of the neo-developmentalism are diffident, however, when handling the inducing of the aggregate demand category. On the one hand, Sicsú, Paula and Michel mention reducing inequality as a goal, although it does not appear to have a clear economic role in their theoretical framework. On the other hand, Bresser-Pereira suggests that the insufficient domestic demand does not necessarily need to be offset by the increasing of state expenditure, employment or wages: it would be better to focus on external demand (Bresser-Pereira, 2010). It is possible to conclude that while the reduction of inequality is sometimes stressed, it is not a condition, as the strategies devised do not depend on it at all-worse, they sometimes go actually against it. Moraes and Saad-Filho (2011) argue that because the domestic market is not the main goal of neo-developmentalism, it separates them from the structuralism of the Cepal.

In order to obtain the political support for the suggested national development strategy, BresserPereira states that Latin American should build a consensus around it, which involves capitalists, workers, unions, institutions, and the three spheres of the State. They should all peacefully rely on each other in a friendly assembly committed to the common good of the nation's development (BresserPereira, 2009, 2010, 2011). As matter of fact, when the Brazilian Labour Party (PT) was elected in 2002 , its economic agenda was called neo-developmentalist, althought it had several differences to what Bresser-Pereira and his followers sustain. One of the most important political strategies of the PT was the ruling through multiparty arrangements, which was said to be on behalf of a potential greater general public interest. So, let's look into it.

After the failure of the Brazilian neoliberal experience in promoting growth, the government faced the challenge of delivering an alternative strategy to the conventional orthodoxy. The change began with the election of Luiz Inácio Lula da Silva, which in his inaugural speech criticized the social outcomes of previous policies while reinforcing the commitment to monetary stability. Real changes, however, only begun to appear in the second half of his first term, but they were still riddled with contradictions (Boito and Berringer, 2013).

Four major general strategies were pursued through a combination of a few minor projects each. First, the Government launched a programme to overcome extreme poverty, the Bolsa Família, which consisted of monthly cash transfers to low-income families (whose most evident externality was to strengthen effective demand) (Lindert et al., 2007). Second, a public inversions package

\footnotetext{
${ }^{16}$ Most suggestions from Bresser-Pereira articles and books were draft in very general terms, except regarding the maintenance of undervalued exchange rate, over what it was very specific (Bresser-Pereira, 2007:172).
} 
called Programa de Aceleração do Crescimento (PAC, Growth Acceleration Programme)-was aimed at enhancing power distribution, logistics and urban infrastructure (Calixtre, Biancarelli, and Cintra, 2014). The programme was divided in three stages, the first two under Lula, the last under Dilma's presidency. Third, the Government also increased investments in public higher education, emphasizing technological areas such as engineering and biotechnology. Policies and programmes such as Reuni and Prouni (under Lula), alongside Pronatec and Science without Borders (under Dilma), although criticized, contributed to the resumption of the State's prominence in the boosting of higher education (Silva and Ourique, 2012). Fourth, the South-South foreign policy under Lula and Dilma Rousseff sought closer relations with peripheral and developing countries, which historically have been more favourable markets for Brazilian companies (Boito and Berringer, 2013).

From 2002 (Lula's first election) until 2014 (Dilma's re-election) some other measures were taken: (i.) A policy of minimum wage recovery; (ii.) Increased budget and renewed strategies for the Banco Nacional de Desenvolvimento Econômico e Social (BNDES, National Bank for Economic and Social Development); (iii.) Anti-cyclical economic policies (especially promoting the construction industry). Simultaneously, nonetheless, the neoliberal macroeconomic agenda was upheld, making true Boito's statement: 'neo-developmentism is the development policy which is possible within the limits given by the neoliberal capitalist model.' (Boito and Berringer, 2013:32).

Neo-developmentalism coexisted, therefore, with restrictive macroeconomic measures. According to Teixeira and Pinto, the three main guidelines of neoliberal macroeconomic management were kept during the period: inflation targeting, primary surpluses and floating exchange rates (Teixeira and Pinto, 2012). These measures, led by a largely independent Central Bank, aimed to maintain the economic credibility of the country, both internally and externally. Inflation targeting, however, required the maintenance of high interest rates, which constrained private investment and attracted speculative capital while maintaining primary surpluses, limiting state's investment capacity, thus forcing a passive fiscal policy. In addition, the floating exchange rate made the economy hostage of high interest rates, leaving national competitiveness at the mercy of the humour of international markets.

In Brazil we had thus a contradictory economic policy for twelve years. On the one hand, the Government tried to induce private investment by increasing effective demand and public expenditure. On the other hand, the Government was limiting the very availability of capital by increasing the cost of investment and by offering returns with greater liquidity and security. The outcomes were also (necessarily) contradictory. During the outset of the global finance crisis of 2007, Brazil was one the few countries in the World that did not suffer a major recession. In addition, many of the social indicators such as inequality, unemployment, wages, housing and education experienced significant improvements (Pochmann, 2013). Brazilian economic performance, nonetheless, in terms of GDP, macroeconomic performance index, private investment, financial external vulnerability, cost of foreign-exchange reserves, as well as the advancement of industry and technology sectors, among others, were discrete, sometimes dubious or even notably mediocre (Gonçalves, 2013). 
The latest results of the Brazilian economy shows that neo-developmentalism follows the same old course: despite all the promises, it is just ineffective to find the holy grail of development. And it could not be otherwise, since its collage of gods, villains, and heroes does not offer anything new. The blasphemy did not pay off. In spite of having some internal logic, its theoretical framework is just another tale as shallow and as distant from reality as any other here discussed.

Trying to reduce neo-developmentalism to one great feature, we can say that its macroeconomics all revolves around the exchange-rate regime. Indeed it is not enough — not even if guided by strengthened better institutions, as claimed. Furthermore, the most important and challenging problem - political support - was handled through an inaccurate, even naive belief that Brazilian capitalists would all join hands towards development. Brazilian capitalist fractions of class are not homogeneous nor are they lead by a consensual goal. And it will not be different only because a bunch of scholars wish so. Last presidential election and its further political development is a good example of that fracture. President Dilma was re-elected by a very small margin of votes in 2014, which followed in two years full of political persecution by the media and opposition parties associated with the traditional elites. That culminated in a constitutional coup d'etat which brought even more political, economic and social uncertainties (Pinto, Filgueiras, and Gonçalves, 2015; Fagnani, 2016). That means a consensus is mostly off the table.

As with every theory, its supporters will always defend it by saying it failed because it was not 'correctly followed.' 'The Government did not use the exchange-rate regime to reinforce national entrepreneur', some may claim. 'They did not do the reforms to improve the management of the administrative apparatus and strengthen the state', may scream others. 'Politicians were unable to build a consensus around the idea of development', never-saying-how-it-could-be-done supporters may argue. The theory, therefore, can never be blamed. It is never said, however, why have they chosen to turn a blind eye to the discussion on the historical [im]balance of power amongst nations, on Brazilian dependency in the International Division of Labour, on the lack of labour and popular support involving restrictive administrative reforms or on regional and social disparities in a continent-sized country as Brazil, to mention only a few. They never explained how such a gross oversimplification of reality, to say the least, would actually lead to development.

In our opinion, Neo-developmentalism is a myth as any other, as it simplifies a complex social process to suggest policies that are sustained by no more than wishful thinking. Its overturn was just a fuzz. It is not surprising that the same mythical structure is here too reproduced. Its hero, national development strategy, tries with bravery to push a middle-income country as Brazil to the little club of the developed. The antagonist, the great villain of overvalued exchange rate, exposes the damsel country to the titans of international competition. The magic weapon of our hero is no practical measure, but a moral transformation: Brazilian society must unite around a consensus.

The greater good is at stake; the Eldorado, just around the corner. 


\section{CONCLUSIONS}

The capitalist reasoning is plenty of narratives about a large range of phenomena, from economic (human) behaviour to macroeconomic policies. As argued before, a myth is a symbolic structure surrounded by several distinct versions and derivations, which, attached to a linguistic structure, seek to explain reality.

As we have discussed, the narratives about economic development can be understood as contemporary myths. The so called theories of development are built upon a simple four-dimensional structure where villains, heroes, sagas of salvation and moral lessons take place. Moreover, all share some core assumptions, leading one to wonder why are they, until today, basis for decision-making policies all over the world.

Brazilian neo-develomentalism - theoretically or pragmatic - is no different. Besides the fact that it reproduces the mythological development structure, its empirical counterpart, the development policies adopted by the Brazilian Government since 2002, did not reach a prodigious success. Although there have been obvious social gains under the Brazilian Labour Party government, the macroeconomic performance of the country does not indicate a development jump. In other words, neo-developmentalism is both mythological and inefficient.

Myths of development are ubiquitous, as they have a structural social role. The myth is a semiotic system that offers an interpretation of reality as if it were reality itself. Even if those narratives have not yet cultivated any promised lands, why do they still play such an important role in our society? Why do theories of development keep on being understood as reliable (scientific) if they keep failing? Why do such narratives emphasize policies that specifically contradicts every alternative to capitalism? These and other questions are indeed invitations to future research. 


\section{REFERENCES}

ABBAGNANO, Nicola. Dicionário de filosofia. São Paulo: WMF; Martins Fontes, 2012.

AYERS, Alison J.; SAAD-FILHO, Alfredo. Democracy against neoliberalism: paradoxes, limitations, transcendence. Critical Sociology, v. 41, n. 4-5, p. 597-618, 2015.

BARTHES, Roland. Mythologies. New York: Noonday Press, 1972.

BAUDRILLARD, Jean. Simulacros e simulação. Lisbon: Relógio D’Água, 1991.

BOETTKE, Peter J. What is wrong with neoclassical economics (and what is still wrong with Austrian economics). In: FOLDVARY, Fred E. (Org.). Beyond neoclassical economics: heterodox approaches to economic theory. Cheltenham, UK: Edward Elgar Publishing, 1996. p. 22-40.

BOITO JR., Armando; BERRINGER, Tatiana. Brasil: classes sociais, neodesenvolvimentismo e política externa nos governos Lula e Dilma. Revista de Sociologia Política, v. 47, n. 21, p. 31-38, 2013.

BOYER, Robert. Prefácio: do "Consenso de Washington" à "proposta de São Paulo". In: BRESSERPEREIRA, Luís Carlos. Globalização e competição. Rio de Janeiro: Elsevier, 2009. p. I-IX.

BRESSER-PEREIRA, Luís Carlos. A graphic explanation on how a tax on exports neutralizes the Dutch disease without costs to exporters. Revista de Economia Política, v. 32, n. 4 (129), p. 700-702, 2012a.

BRESSER-PEREIRA, Luís Carlos. A taxa de câmbio no centro da teoria do desenvolvimento. Estudos Avançados, São Paulo, v. 26, n. 75, p. 7-28, 2012 b.

BRESSER-PEREIRA, Luís Carlos. Desenvolvimento e crise no Brasil: história, economia e política de Getúlio Vargas a Lula. São Paulo: Editora 34, 2003.

BRESSER-PEREIRA, Luís Carlos. Estado e mercado no novo desenvolvimentismo. Nueva Sociedad, v. 210, p. 156-173, 2007.

BRESSER-PEREIRA, Luís Carlos. Globalização e competição. Rio de Janeiro: Elsevier, 2009.

BRESSER-PEREIRA, Luís Carlos. Novo desenvolvimentismo: uma proposta para a economia do Brasil. Nueva Sociedad, v. 230, p. 58-72, 2010.
BRESSER-PEREIRA, Luís Carlos. O Brasil e o novodesenvolvimentismo. Interesse Nacional, v. 13, n. 4, p. 76-85, 2011.

BRESSER-PEREIRA, Luís Carlos. The Dutch disease and its neutralization: a Ricardian approach. Brazilian Journal of Political Economy, v. 28, n. 1, p. 47-71, 2008.

BRESSER-PEREIRA, Luís Carlos. The value of the exchange rate and the Dutch disease. Revista de Economia Política, v. 33, n. 3 (132), p. 371-387, 2013.

BRESSER-PEREIRA, Luís Carlos; GALA, Paulo. Macroeconomia estruturalista do desenvolvimento. Revista de Economia Política, São Paulo, v. 30, n. 4 (120), p. 663-686, 2010.

BRESSER-PEREIRA, Luís Carlos; GALA, Paulo. Por que a poupança externa não promove crescimento. Revista de Economia Política, São Paulo, v. 27, n. 1 (105), p. 3-19, 2007.

BRESSER-PEREIRA, Luís Carlos; THEUER, Daniela. Um estado novo-desenvolvimentista na América Latina? Economia e Sociedade, v. 21, special number, p. 811-829, 2012.

CAILLÉ, Alain. O princípio de razão, o utilitarismo e o antiutilitarismo. Sociedade e Estado, v. 16, n. 1, p. 26-56, 2001.

CALIXTRE, André B.; BIANCARELLI, André M.; CINTRA, Marcos A. M. Presente e futuro do desenvolvimento brasileiro. Brasília: Ipea, 2014.

CAMPBELL, Joseph. The hero with a thousand faces. Princeton, US: Princeton University Press, 2004.

CHANG, Ha-Joon. Kicking away the ladder: development strategy in historical perspective. London: Anthem Press, 2002.

CHESNAIS, François. A mundialização do capital. Tradução de Silvana Finzi Foá. São Paulo: Xamã, 1996.

CODDINGTON, Alan. Keynesian economics: the search for first principles. Journal of Economic Literature, v. 14, n. 4, p. 1258-1273, 1974.

CRISTALDO, Rômulo C. Administração política e internacionalização do capital: o papel do Estado na formação das bases para a internacionalização da indústria brasileira da construção civil, 1964-1979. Revista Brasileira de Administração Política, v. 7, n. 1, p. 143-165, 2014. Available at: <www.portalseer.ufba. 
br/index.php/rebap/article/view/15609/10723>. Accessed on: 8 Jan. 2016.

DOUGLAS, Roy. World crisis and British decline, 1929-56. London: Palgrave Macmillan, 1986.

DURKHEIM, Emile. The elementary forms of religious life. Tradução de Karen E. Fields. New York: The Free Press, 1995.

EDERINGTON, Josh; McCALMAN, Phillip. Infant industry protection and industrial dynamics. Journal of International Economics, v. 84, p. 37-47, 2011.

ESCOBAR, Arturo. Encontering development: the making and unmaking of the third world. Princeton, NJ: Princeton University Press, 1995.

FAGNANI, Eduardo. Por trás do golpe: impeachment do processo civilizatório. Le Monde Diplomatique Brasil, v. 105, 2016. Available at: <www.diplomatique. org.br/artigo.php?id=2066>. Accessed on: 10 June 2016.

FAJNZYLBER, Fernando. La industrialización trunca de América Latina. Mexico, DF: Nueva Imagem, 1983.

FAZZARI, Steven. Keynesian theories of investment: neo-, post- and new. Revista de Economia Política, v. 9, n. 4, p. 101-111, 1989.

FILGUEIRAS, Luís. A natureza do atual padrão de desenvolvimento brasileiro e o processo de desindustrialização. Programa de Bolsas Celso Furtado, 2012. Mimeografado. Available at: $<w w w$. ie.ufu.br/sites/ie.ufu.br/files/Anexos/Bookpage/ Filgueiras_padrao\%20de\%20desenvolvimento\%20 brasileiro_0.pdf $>$. Accessed on: 10 May 2016.

FURTADO, Celso. O mito do desenvolvimento econômico. São Paulo: Círculo do Livro, 1974.

FURTADO, Celso. Teoria epolítica do desenvolvimento econômico. São Paulo: Abril Cultural, 1983.

GONÇALVES, Reinaldo. Balanço crítico da economia brasileira nos governos do partido dos trabalhadores. UFRJ Working Papers, 2013. Available at: <www.ie.ufrj.br/>. Accessed on: 13 May 2014.

HARVEY, David. A brief history of neoliberalism. Oxford, UK: Orford University Press, 2005.

HARVEY, David. Seventeen contradictions and the end of capitalism. New York: Oxford University Press, 2014.
HODGSON, George M. The approach of institutional economics. Journal of Economic Literature, v. 36, n. 1, p. 166-192, 1998.

IBARRA, David. O neoliberalismo na América Latina. Revista de Economia Política, v. 31, n. 2, p. 238-248, abr./jun. 2011. Available at: <www. scielo.br/pdf/rep/ v31n2/04.pdf>. Accessed on: 25 Jan. 2016.

KELLY, Michael. The 1992 campaign: the democrats, Clinton and Bush compete to be champion of change; democrat fights perceptions of bush gain. The New York Times, 31 Oct. 1992. p. 6. Available at: <www.nytimes.com/1992/10/31/us/1992-campaigndemocrats-clinton-bush-compete-be-championchange-democrat-fights.html>. Accessed on: 12 Jan. 2016.

KEYNES, John M. A tract on monetary reform. London: Macmillian, 1924.

KEYNES, John M. The general theory of employment, interest and money. London: Macmillian; Cambridge University Press, 1936.

KLIKAUER, Thomas. What is managerialism. Critical Sociology, v. 41, n. 7-8, p. 1103-1119, 2015.

KINDLEBERGER, Charles P. Manias, pânicos e crashes: um histórico das crises financeiras. Tradução de Eduardo Kraszczuk. São Paulo: Nova Fronteira, 2000.

LEMPERT, David. What is development? What is progress? The social science and humanities of utopia and futurology. Journal of Developing Societies, v. 30, n. 2, p. 223-241, 2014.

LÉVI-STRAUSS, Claude. Antropologia estrutural. Rio de Janeiro: Tempo Brasileiro, 1970.

LINDERT, Kathy et al. The nuts and bolts of Brazil's Bolsa Família program: implementing conditional cash transfers in a decentralized context. World Bank Working Papers, v. 0709, p. 1-144, 2007. Available at: <www.worldbank.org/>. Accessed on: 10 Dec. 2015.

LIST, Friedrich. Sistema nacional de economia política. Tradução de Antônio Alves Cury. São Paulo: Abril Cultural, 1983. (Os Economistas).

MARINI, Ruy M. América Latina: dependência e integração. São Paulo: Página Aberta, 1992. 
MARX, Karl. O capital: para a crítica da economia política. Tradução de Paul Singer. São Paulo: Nova Cultural, 1982. v. 3. (Os Economistas).

MELITZ, Marc J. When and how should infant industries be protected? Journal of International Economics, v. 66, p. 177-196, 2005.

MÉSZÁROS, István. A crise estrutural do capital. Tradução de Francisco Raul Cornejo. São Paulo: Boitempo, 2009.

MÉSZÁROS, István. The power of ideology. London: Zeb Books, 2005.

MORAIS, Lecio; SAAD-FILHO, Alfredo. Da economia política à política econômica. Revista de Economia Política, v. 31, n. 4, p. 507-527, 2011.

MORENO-BRID, Juan-Carlos; BOSCH, Jaime R. Desarrollo y crecimiento en la economía mexicana: una perspectiva histórica. Mexico, DF: Fondo de Cultura Económica, 2010.

NASSIF, André; FEIJÓ, Carmem. Liberal versus neo-developmental convention to growth: why has Brazil shown a poor performance since the 1980s? Brazilian Journal of Political Economy, São Paulo, v. 33, n. 4, p. 555-576, Oct./Dec. 2013.

NELSON, Richard R. Sistemas nacionais de inovação: retrospecto de um estudo. In: NELSON, Richard R. As fontes do crescimento econômico. São Paulo: Editora Unicamp, 2006. p. 427-468.

NELSON, Richard R.; WINTER, Sidney J. An evolutionary theory of economic change. Cambridge, US: Harvard University Press, 1982.

NORTH, Douglass C. The role of institutions in economic development. Discussion Paper Series of United Nations Economic Commission for Europe, n. 2, 2003.

O'CONNOR, James. Accumulation crisis. New York: Basil Blackwell, 1984.

O'CONNOR, James. The fiscal crisis of the State. 2. ed. New York: St. Martin's Press, 2001.

PERSKY, Joseph. The ethology of homo economicus. Journal of Economic Perspectives, v. 9, n. 2, p. 221231, 1995.

PIKETTY, Thomas. O capital no século XXI. Tradução de Monica Baumgarten de Bolle. Rio de Janeiro: Intrínseca, 2014.
PINTO, Eduardo C.; FILGUEIRAS, Luís; GONÇALVES, Reinaldo. Governo Dilma, PT, esquerda e impeachment: três interpretações da conjuntura econômica e política. Textos para discussão IE-UFRJ, v. 15, 2015. Available at: <www.ie.ufrj.br/ images/pesquisa/publicacoes/discussao/2015/TD_ IE_015_2015_PINTO_FILGUEIRAS_GONALVES. pdf $>$. Accessed on: 21 Jan. 2016.

POCHMANN, Mário. Políticas públicas e situação social na primeira década do século XXI. In: SADER, Emil (Org.). 10 anos de governos pós-neoliberais no Brasil: Lula e Dilma. São Paulo: Boitempo, 2013. p. $145-155$.

QURESHI, Emran; SELLS, Michael A. The new crusades: constructing the Muslim enemy. New York: Columbia University Press, 2003.

RIAZ, Suhaib et al. Rhetoric of epistemic authority: defending field positions during the financial crisis. Human Relations, v. 20, n. 20, p. 1-29, 2016. Available at: <http://hum.sagepub.com/content/ early/2016/05/13/0018726715614385>. Accessed on: 9 June 2016.

RILEY, Dylan. Property leading the people? New Left Review, v. 95, p. 109-125, 2015.

RIVERO, Oswaldo. The myth of development: nonviable economies and the crisis of civilization. New York: Zed Book, 2010

SANTOS, Reginaldo S.; GOMES, Fábio G. Apresentação: funções do gerencialismo na crise da administração política do capitalismo. Revista Brasileira de Administração Política, v. 7, n. 2, p. 5-10, 2014.

SANTOS, Theotônio dos. A teoria da dependência. Rio de Janeiro: Civilização Brasileira, 2000.

SANTOS FILHO, Onofre. O fogo de Prometeu nas mãos de Midas: desenvolvimento e mudança social. In: CAMPOS, Taiane las C. (Org.). Desenvolvimento, desigualdades e relações internacionais. Belo Horizonte: Editora PUC Minas, 2005. p. 13-75.

SAULL, Richard. Capitalist development and the rise and 'fall' of the far-right. Critical Sociology, v. 41, n. 4-5, p. 619-639, 2015.

SCHUMPETER, Josef A. Capitalismo, socialismo e democracia. Tradução de Ruy Jungmann. Rio de Janeiro: Fundo de Cultura, 1961. 
SCHUMPETER, Josef A. Teoria do desenvolvimento econômico: uma investigação sobre lucros, capital, crédito, juro e o ciclo econômico. Tradução de Maria S. Possas. São Paulo: Nova Cultural, 1997. (Os Economistas).

SICSÚ, João; PAULA, Luiz F. de; MICHEL, Renalt. Por que novo-desenvolvimentismo? Revista de Economia Política, v. 27, n. 4, p. 507-524, 2007.

SILVA, Jorge P. da; OURIQUE, Maiane L. H. A expansão da educação superior no brasil: um estudo de caso Cesnors. Revista Brasileira de Estudos Pedagógicos, v. 93, n. 233, p. 215-230, 2012.

SINGER, Hans W. Editorial: the Golden age of the Keynesian consensus - the pendulum swings back. World Development, v. 25, n. 3, p. 293-295, 1997.

SOLOW, Robert M. A contribution to the theory of economic growth. The Quarterly Journal of Economics, v. 70, n. 1, p. 65-94, 1956.

SOUZA, Nilson A. de. A longa agonia da dependência: economia brasileira contemporânea. São Paulo: Alfaômega, 2005.

SUNKEL, Osvaldo; PAZ, Pedro. A teoria do desenvolvimento econômico. São Paulo: Difel, 1976.

TEIXEIRA, Rodrigo A.; PINTO, Eduardo C. A economia política dos governos FHC, Lula e
Dilma: dominância financeira, bloco no poder e desenvolvimento econômico. Economia e Sociedade, v. 21, n. 4, n. esp., p. 909-941, Dec. 2012.

TYMOIGNE, Eric; LEE, Frederic S. Post Keynesian economics since 1936: a history of a promise that bounced? Journal of Post Keynesian Economics, v. 26, n. 2, p. 273-288, 2003.

WILLIAMSON, John. Latin American adjustment: how much has happened? Washington, DC: Institute for International Economics, 1990.

WILLIAMSON, Oliver E. Economic institutions: spontaneous and intentional governance. Journal of Law, Economics, \& Organizations, v. 7, n. esp., p. 159-187, 1991.

WILLIAMSON, Oliver E. Transaction-cost economics: the governance of contractual relations. Journal of Law and Economics, v. 22, n. 2, p. 233-261, 1979.

ZIZEK, Slavoj. Bem-vindo ao deserto do real: cinco ensaios sobre o 11 de setembro e datas relacionadas. Tradução de Paulo Cezar Castanheira. São Paulo: Boitempo, 2003.

ZIZEK, Slavoj. Primeiro como tragédia, depois como farsa. Tradução de Maria Beatriz de Medina. São Paulo: Boitempo, 2011.

\section{Rômulo Carvalho Cristaldo}

$\mathrm{PhD}$ in Administration at the NPGA-UFBA; Adjunct Professor at Faculty of Administration, Accounting Sciences and Economics at Universidade Federal da Grande Dourados (Face-UFGD).

E-mail: r.c.cristaldo@gmail.com.

\section{Juliana Rodrigues de Senna}

PhD candidate in International Relations at Vrije Universiteit. E-mail: julianarsenna@gmail.com.

\section{Lara Sousa Matos}

$\mathrm{PhD}$ candidate in Administration at the NPGA-UFBA; Research and Dissemination Coordinator at Superintendence of Solidary Economy (Sesol) of the State Government of Bahia. E-mail: lara_andrade@hotmail.com. 